\title{
PENGARUH PENGGUNAAN TALAS (Xanthosoma sagittifolium) TERHADAP MUTU DAN TINGKAT PENERIMAAN PANELIS PADA PRODUK ROTI, PASTEL, PANCAKE, COOKIES, DAN BUBUR TALAS
}

\author{
The Effect of Using Taro (Xanthosoma sagittifolium) on Quality and Panelists \\ Acceptance Level on Taro Products of Bread, Pastel, Pancake, Cookies, and Porridge
}

\author{
Wilsa Hermianti * dan Firdausni \\ Balai Riset dan Standardisasi Industri Padang \\ JI. Raya LIK No. 23 Ulu Gadut Padang \\ *e-mail: wilsadjaswir@gmail.com
}

Diterima: 8 Mei 2016, revisi akhir: 8 Junil 2016 dan disetujui untuk diterbitkan: 14 Juni 2016

\section{ABSTRAK}

Talas kimpul (Xanthosoma sagittifolium) mengandung karbohidrat dan serat yang tinggi sehingga dapat berfungsi sebagai sumber bahan pangan karbohidrat. Penelitian terdahulu telah dilakukan teknologi pembuatan talas blok (Hermianti et al, 2010). Pada penelitian ini dilakukan penggunaan talas blok untuk pembuatan aneka produk makanan basah, semi basah, dan makanan kering seperti roti, pastel, cookies, pancake, dan bubur talas dengan mensubstitusi tepung terigu dan tepung beras. Penelitian ini bertujuan untuk mengetahui jumlah penggunaan talas yang memberikan hasil yang optimal dalam pembuatan beberapa produk tersebut sehingga dihasilkan pangan dengan mutu yang baik dan disukai. Penelitian substitusi terigu dengan talas yang dilakukan dalam pembuatan roti, pastel, dan cookies $0 \%$ (kontrol/ tanpa talas blok), $25 \%, 50 \%$ dan $75 \%$, untuk pancake dengan formula talas dengan terigu $0 \%$ (kontrol/tanpa talas blok), 30\%, 50\%,100\%, sedangkan untuk bubur talas dengan formula talas dengan tepung beras $0 \%$ (kontrol/tanpa talas blok), 30\%, $50 \%$, dan $100 \%$. Analisis kimia dilakukan terhadap bahan baku talas blok meliputi kadar air, kadar abu, kadar pati, dan protein sedangkan untuk produk olahan pangan dilakukan uji organoleptik (warna, aroma, rasa dan tekstur) berdasarkan tingkat penerimaan panelis. Produk cookies talas dan roti talas yang paling disukai panelis dianalisis kandungan lemak, protein, karbohidrat dan kalorinya serta daya simpan untuk produk makanan kering (cookies). Hasil penelitian menunjukkan talas blok mengandung kadar air $12,40 \%$, kadar abu $1,12 \%$, kadar pati $73,37 \%$, amilosa $2,88 \%$, amilopektin $70,49 \%$ dan protein $3,4 \%$. Hasil uji organoleptik dengan hasil yang optimal dan lebih disukai adalah roti dan pastel dengan penggunaan $25 \%$ talas, cookies dengan penggunaan $50 \%$ talas, pancake dengan formula talas dengan tepung $50 \%$ dan bubur dengan pemakaian talas blok $30 \%$.

\section{Kata Kunci: Roti talas, pastel talas, pancake talas, cookies talas, dan bubur talas}

\section{ABSTRACT}

Kimpul taro (Xanthosoma sagittifolium) contains high enough of starch and fibers so that it can functionate as a non-rice food carbohydrates source. Previous research was done a research about taro block process technology (Hermianti et al., 2010). In this study, taro blocks was used for making of various wet food, semi-wet and dry food products such as bread, pies, cookies, pancakes, and taro porridge by substituting wheat flour and rice flour. The research was aimed to find out the composition of the appropriate use of taro block in making of various food products with a good quality and preferred. Bread, pies, and cookies were made with percentage of taro block $0 \%$ (control/without taro block), 25\%, 50\%, and 75\%, whereas for pancakes with formula of taro block 0\% (control/without taro block), 30\%, 50\%, 100\%. Porridge was made to subtitute rice flour with percentage of taro block $0 \%$ (control/without taro block), 30\%, 50\%, and $100 \%$. The chemical analysis of taro block was done on several parameter included moisture content, ash content, starch, and protein, while for processed food products were conducted the organoleptic test (color, aroma, taste, and texture) based on the panelists acceptance level. The most 
products of taro cookies and taro bread preferred by panelists were analyzed the fat content, protein, carbohydrates and calories and storability for dry food products (cookies). The results showed that taro block moisture content $12.40 \%$, ash content $1.12 \%$, starch content $73.37 \%$, amylose $2.88 \%$, amylopectin $70.49 \%$, and protein $3.4 \%$. The organoleptic test with optimal results and preferably were bread and pastel with the use of taro $25 \%$, cookies with the use of taro $50 \%$, taro pancake formula with $50 \%$ taro block, and porridge with usage of taro block $30 \%$.

\section{Keywords: Taro bread, taro pastel, taro pancake, taro cookies, and taro porridge}

\section{PENDAHULUAN}

Diversifikasi pangan merupakan upaya memperluas pilihan masyarakat dalam kegiatan konsumsi terutama untuk bahan pangan pokok yang berbasis sumber daya lokal. Potensi talas sebagai sumber pangan lokal diharapkan dapat menjadi sumber penyediaan bahan pangan karbohidrat non beras, diversifikasi konsumsi pangan lokal, mensubstitusi penggunaan tepung terigu serta pengembangan industri pengolahan makanan.

Talas kimpul (Xanthosoma sagittifolium) adalah tanaman umbi-umbian yang banyak ditemui termasuk famili Areaceae merupakan tumbuhan menahun mempunyai umbi batang palsu yang sebenarnya adalah tangkai daun.

Manfaat utama dari umbi talas menurut Prihatman (2000) adalah sebagai bahan pangan sumber karbohidrat karena mengandung karbohidrat berupa pati yang cukup tinggi. Kandungan pati yang tinggi pada talas sehingga talas dapat sebagai salah satu alternatif sumber pati industri (Rahmawati et al, 2012). Ridal (2003) menyatakan kandungan karbohidrat kimpul sekitar $70,73 \%$. Energi yang terkandung dalam $100 \mathrm{~g}$ tepung kimpul adalah 359,56 kkal, energi yang tinggi dalam tepung kimpul dapat menjadikan tepung ini sebagai sumber energi yang potensial (Indrasti, 2004).

Menurut Suismono (2011) karakteristik kimia tepung kimpul tidak mengandung gluten sehingga produk yang dihasilkan tidak mengembang. Tepung kimpul mempunyai sifat spesifik dengan aroma khas kimpul.

Menurut Slamet dan Tarkotjo (1980) umbi talas mengandung pati yang mudah dicerna kira-kira sebanyak 18,2\%. Karbohidrat dipahami sebagai nutrisi yang banyak dikandung beras namun sebenarnya karbohidrat juga dapat ditemui dalam bahan pangan lain seperti ubi kayu, ubi jalar, talas dan lain sebagainya.

Pemanfaatan umbi talas sebagai bahan pangan masih terbatas, umumnya sebagai makanan tambahan seperti direbus, dikukus, digoreng, dibuat getuk, kolak atau keripik. Umbi talas juga dapat diolah menjadi tepung talas yang lebih luas penggunaannya yaitu dapat digunakan sebagai bahan untuk sop, biskuit, roti, minuman beralkohol, makanan bayi, puding, pasta, permen dan makanan ringan lainnya.

Talas dalam bentuk segar dan tanpa pengolahan menyulitkan dalam transportasi dan umur simpannya hanya $1-2$ minggu. Untuk meningkatkan daya simpannya dan kemudahan dalam penggunaan oleh industri maupun konsumsi masyarakat, telah dilakukan pengolahannya menjadi produk antara berupa talas blok. Talas blok adalah olahan talas dalam bentuk kotak (blok) siap untuk digunakan sebagai bahan baku pembuatan aneka produk pangan. Dalam bentuk talas blok ketahanan simpan lebih tinggi dan mudah dalam transportasi. Pengolahan talas menjadi talas blok telah dilakukan oleh Hermianti, et al (2010).

Pengolahan talas blok menjadi beberapa produk pangan siap konsumsi bertujuan untuk penganekaragaman produk pangan olahan berbahan talas dengan memaksimalkan pemanfaatan talas sebagai substitusi tepung terigu dan tepung beras pada beberapa produk olahan makanan yang direbus, digoreng, dipanggang dan dioven.

\section{METODOLOGI PENELITIAN}

Bahan yang digunakan adalah talas blok dari talas kimpul (Xanthosoma sagittifolium), tepung terigu, tepung maizena, susu bubuk, mentega, butter, telur, gula pasir, gula halus, garam, vanile, baking 
powder, ragi roti, selai strawberry, madu, minyak goreng, cokelat, daun bawang, dan sup, merica, bawang merah, bawang putih, bawang Bombay, daging ayam, bahan bakar, bahan kemasan dan bahan kimia untuk pengujian $(\mathrm{HCl}, \mathrm{NaOH}, \mathrm{KI}$, glukosa, aquades, methylen blue, Fehling $A$, Fehling $B$, kalium, sodium tartrat, $\mathrm{H}_{2} \mathrm{SO}_{4}$, indikator phenolphtalein, asam boraks, $\mathrm{KMNO}_{4}$ ).

Alat-alat yang digunakan adalah alat pengaduk roti (Merk Bosch) dan alat untuk analisis yakni neraca, oven, titrasi, destilator kjedhal, dan furnace.

Rancangan penelitian yang digunakan mencakup pembuatan aneka produk pangan dari talas berupa pangan basah, semi basah dan kering dengan rancangan sebagai berikut:

1. Makanan basah untuk bubur substitusi talas terhadap tepung beras dengan perlakuan kontrol tanpa penggunaan talas blok, dan penggunaan talas blok $30 \%, 50 \%$ serta $100 \%$.

2. Makanan semi basah dipanggang yakni pancake substitusi terigu dengan perlakuan kontrol tanpa penggunaan talas blok, dan penggunaan talas $30 \%$, $50 \%$ dan $100 \%$

3. Makanan semi basah digoreng yakni pastel substitusi terigu dengan perlakuan kontrol tanpa penggunaan talas blok, dan penggunaan talas blok $25 \%, 50 \%$ dan $75 \%$.

4. Makanan semi basah dioven yakni roti substitusi terigu dengan perlakuan kontrol tanpa penggunaan talas blok, dan penggunaan talas blok $25 \%, 50 \%$ dan $75 \%$.

5. Makanan kering yakni cookies substitusi terigu dengan perlakuan kontrol tanpa penggunaan talas blok, dan penggunaan talas blok $50 \%, 75 \%$ dan $100 \%$.

\section{Pembuatan Produk Pangan dari Talas Blok}

Pembuatan produk-produk pangan dari talas blok yang dilakukan seperti pada Gambar 1-Gambar 5.

\section{Bubur Talas}

Talas blok

(jumlah sesuai perlakuan)

Dihancurkan

Dimasak

Ditambah garam, merica, air kaldu, wortel, daun sup, daun bawang, bawang bombay, bawang merah goreng, dan daging ayam suir

Diaduk dan dimasak sampai kembang

$$
\text { Bubur Talas }
$$

Gambar 1. Diagram Alir Proses Pembuatan Bubur Talas

\section{Pancake Talas}

Talas Blok

(jumlah sesuai perlakuan)

Dihancurkan/dihaluskan

Ditambah telur, garam, mentega cair, susu bubuk, gula dan air

Diaduk rata

Dituangkan ke dalam panci Teflon

Dibakar hingga kering

Dihias dengan Vla pasta talas

$$
\text { Pancake Talas }
$$

Gambar 2. Diagram Alir Proses Pembuatan Pancake Talas 


\section{Pastel Talas}

Talas Blok

(jumlah sesuai perlakuan)

Dihancurkan/dihaluskan

Ditambah terigu, mentega, telur, garam dan air

Diaduk sampai kalis

Adonan ditipiskan

Dicetak dan diisi dengan ragout dari wortel, kentang, dan ayam

\section{Digoreng \\ Pastel Talas}

Gambar 3. Diagram Alir Proses Pemuatan Pastel Talas

\section{Roti Talas}

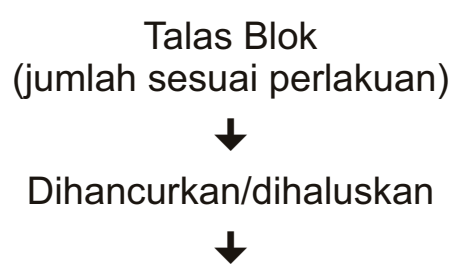

Ditambah terigu, gula, ragi, tepung susu, telur, air es, butter, mentega, dan garam

Diaduk sampai kalis

Dibentuk dan dibiarkan kembang

Dioles dengan bahan olesan

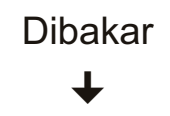

Roti Talas

Gambar 4. Diagram Alir Proses Pembuatan Roti Talas

\section{Cookies Talas}

Talas blok

(jumlah sesuai perlakuan)

$\downarrow$

Dihancurkan/dihaluskan

Telur, gula halus, mentega, butter dikocok

Ditambah talas, terigu,

vanile, baking powder, maizena, susu bubuk

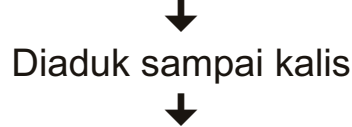

Dibentuk dan dihias sesuai selera (diisi dengan cokelat)

Dibakar dengan oven

Cookies Talas

Gambar 5. Diagram Alir Proses Pembuatan Cookies Talas

\section{Analisis}

Analisis yang dilakukan meliputi: analisis kimia bahan baku talas blok yakni kadar air, abu, pati, amilosa, amilopektin dan protein dan uji organoleptik warna, aroma, rasa dan tekstur produk makanan dari talas blok berupa bubur talas, pancake, pastel, roti, dan cookies talas berdasarkan tingkat penerimaan panelis dengan skala numerik 5 = sangat suka, 4 = suka, 3 = cukup suka, 2 = kurang suka, 1 = tidak suka. Produk olahan talas yang tahan sampai 3 hari yakni roti dan cookies talas yang memberikan nilai optimal dilakukan analisis kadar karbohidrat, lemak, protein dan kalori sedangkan untuk produk makanan yang tahan lebih dari satu bulan juga diamati secara visual dan dianalisis kadar air selama penyimpanan.

\section{HASIL DAN PEMBAHASAN}

\section{Hasil AnalisisTalas Blok}

Talas terlebih dahulu dibuat menjadi talas blok dengan cara talas dicuci/dibersihkan, ditiriskan, dikupas, diiris lalu direndam dalam larutan natrium 
metabisulfit 0,1\% selama 20 jam, kemudian dicuci, ditiriskan, dihaluskan, dipress lalu dicetak seperti blok dan dikeringkan (Hermianti et al, 2010). Hasil analisis talas blok meliputi kadar air, kadar abu, kadar pati, amilosa dan amilopektin, serta kadar protein seperti terlihat pada Tabel 1.

Tabel 1. Hasil uji fisiko kimia dari talas blok dari Xanthosoma sagittifolium

\begin{tabular}{|l|c|}
\hline Parameter yang diamati & Jumlah \\
\hline Kadar air (\%) & 12,40 \\
\hline Kadar abu (\%) & 1,12 \\
\hline Kadar pati (\%) & 73,37 \\
\hline Kadar amilosa (\%) & 2,88 \\
\hline Kadar amilopektin (\%) & 70,49 \\
\hline Kadar protein (\%) & 3,40 \\
\hline
\end{tabular}

Sumber : Hermianti et al (2010)

Hasil analisis talas blok seperti pada Tabel 1 menunjukkan kadar air talas blok $12,40 \%$. Kadar air sangat mempengaruhi ketahanan simpan produk. Penggunaannya sebagai pengganti terigu memenuhi persyaratan dari kadar air sesuai SNI 3751 : 2009 yakni tepung terigu sebagai bahan makanan dengan kadar air maksimal $14,5 \%$, begitu juga dengan tepung beras sesuai SNI 3549 : 2009 tepung beras maksimal persyaratan kadar airnya $13 \%$. Menurut Herman (1991) kadar air sangat berpengaruh terhadap mutu bahan pangan. Richana Nur et al (2004) menyatakan jumlah air dalam bahan akan mempengaruhi daya tahan bahan terhadap kerusakan yang disebabkan oleh mikroba maupun serangga. Sediaoetama (1996) menyatakan bahwa kadar air yang tinggi akan menguntungkan pertumbuhan mikroba yang akan menyebabkan kerusakan bahan pangan. Pengolahan talas menjadi talas blok bertujuan salah satunya untuk mengurangi kadar air sampai batas tertentu sehingga pertumbuhan mikroba dan aktivitas enzim penyebab kerusakan pada tepung dan pati dapat dihambat. Batas kadar air mikroba masih dapat tumbuh ialah 14-15\% (Fardiaz, 1989).

Hasil analisis kadar abu talas blok mengacu pada SNI tepung terigu dan tepung beras sedikit lebih tinggi dari yang dipersyaratkan dimana untuk tepung terigu maksimal kadar abu $0,7 \%$ dan tepung beras maksimal $1 \%$. Tingginya kadar abu pada bahan pangan dapat terjadi karena proses pengolahannya.

Kadar pati talas blok dari talas jenis Xanthosoma sagittifolium cukup tinggi yakni $73,37 \%$ dengan komposisi amilosa 2,88\% dan amilopektin $70,49 \%$. Hal ini sesuai dengan pendapat Srihari dan Lingganingrum (2014) bahwa tepung talas mengandung amilopektin yang cukup tinggi dimana kandungan amilopektin tersebut membuat tepung talas menjadi lengket dan pulen sehingga baik untuk dibuat aneka kue. Ditambahkan oleh Saptoningsih (2013) tepung talas berpotensi untuk digunakan sebagai ingredient untuk pembuatan produk baru ataupun untuk mengganti tepungtepung konvensional. Tepung talas memiliki kapasitas absorpsi air yang tinggi, granula patinya tahan panas sehingga memungkinkan digunakan sebagai pengental pada produk yang diolah pada suhu tinggi disamping itu juga memiliki kapasitas absorpsi lemak yang tinggi. Kapasitas absorpsi airnya yang tinggi maka tepung ini juga sangat potensial digunakan untuk mempertahankan flavor, memperbaiki palatabilitas dan memperpanjang umur simpan produk seperti cookies, mie, dan cake.

Kadar protein talas blok seperti tercantum pada Tabel 1 yakni 3,40\%. Bila dibandingkan dengan tepung terigu, kadar protein dari talas blok ini masih jauh dibawah tepung terigu. Menurut US Wheat Associates (1983) berdasarkan kandungan proteinnya tepung terigu dibedakan atas terigu protein tinggi (hard flour) yakni $12 \%$ ke atas, tepung terigu dengan kandungan protein sedang (medium flour) $10-11 \%$ dan tepung terigu dengan protein rendah (soft flour) $8-9 \%$. Terigu dengan protein tinggi memiliki daya kembang yang baik serta dapat menghasilkan adonan yang kuat dan kenyal. Sedangkan terigu dengan protein yang rendah memiliki daya serap air yang juga rendah. Menurut Soekarto et al (2008) terigu dengan protein $12-13 \%$ digunakan untuk pembuatan roti, terigu dengan protein 9,5-11\% digunakan untuk pembuatan cake, terigu dengan kadar protein 7-8,5\% digunakan untuk pembuatan mi basah, mi kering dan mi instan sedangkan terigu dengan kadar protein kurang dari $7 \%$ 
digunakan untuk tepung gorengan. Ditambahkan oleh Sufi (2009) tepung terigu protein tinggi cocok untuk bahan pembuatan roti, protein sedang cocok untuk pembuatan cake dan kue-kue sedangkan tepung terigu dengan protein rendah cocok untuk kue kering atau cookies.

\section{Uji Organoleptik Produk Pangan dari Talas Blok}

\section{Bubur Talas}

Hasil uji organoleptik talas yang dilakukan oleh panelis menurut tingkat penerimaan seperti terlihat pada Gambar 6 . Penggunaan talas sebagai substitusi tepung beras pada pembuatan bubur dapat mencapai $100 \%$, namun setelah dilakukan uji organoleptik ternyata bubur dengan substitusi talas blok $30 \%$ dengan nilai warna, rasa dan tekstur menyamai penggunaan tepung beras $100 \%$ (kontrol). Penggunaan talas untuk bubur dapat mencapai $100 \%$ karena untuk membuat bubur dengan proses perebusan tidak memerlukan sifat yang khusus, yang utama hanya mempunyai sifat berikatan dengan air dan mengembang. Mungkin karena panelis belum terbiasa mengkonsumsi bubur talas sehingga persentase penggunaan talas $30 \%$ yang mampu menyamai bubur dari tepung beras secara organoleptik sementara pada beberapa daerah seperti Papua dan Mentawai talas ini merupakan makanan pokok. Bubur talas dapat melancarkan pencernaan sehingga dapat dikonsumsi untuk bayi dengan tingkat alergi yang rendah.

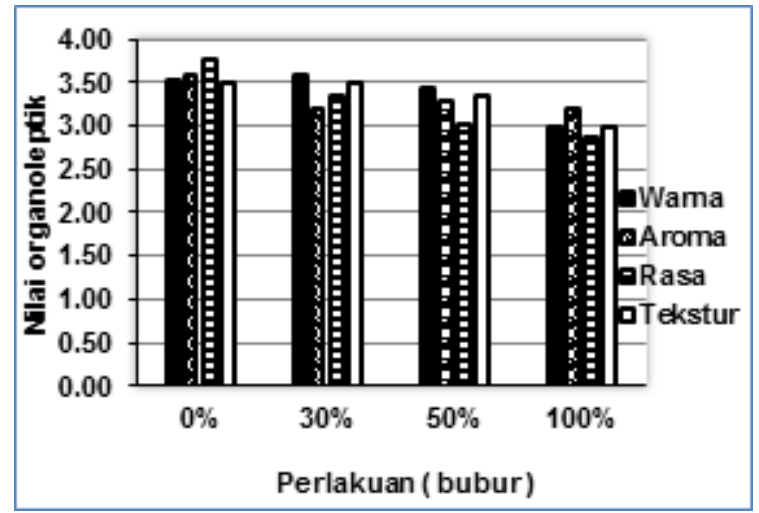

Gambar6. Nilai rata-rata uji organoleptik Bubur dengan substitusi talas blok

\section{Pancake Talas}

Pancake dikenal sebagai makanan ringan untuk sarapan pagi. Pancake dengan standar mutu yang baik adalah dengan daya kembang yang sempurna (Univ Hasanuddin, 2011).

Pada Gambar 7 dapat dilihat nilai organoleptik produk pancake talas. Pancake dapat dibuat dengan talas sampai $100 \%$, namun memberikan tekstur yang kaku sehingga kurang disukai oleh panelis. Pancake dengan substitusi talas blok $50 \%$ memberikan penilaian organoleptik yang lebih disukai. Tekstur yang kaku jika menggunakan talas $100 \%$ pada pembuatan pancake disebabkan karena kandungan gluten (protein) pada talas yang lebih rendah dibanding tepung terigu. Menurut Srihari dan Lingganingrum (2014) 100 gram tepung terigu mengandung kadar protein 8-13 persen gluten (protein) sedangkan 100 gram tepung talas mengandung 1,9 persen protein.

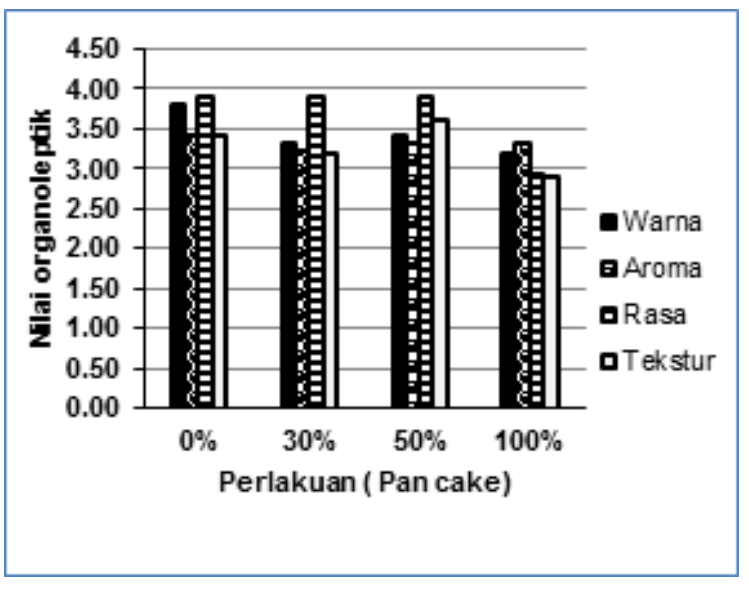

Gambar 7. Nilai rata-rata uji organoleptik pancake dengan substitusi talas blok

\section{Pastel Talas}

Uji organoleptik yang dilakukan terhadap produk olahan talas berupa pastel menunjukkan hasil bahwa penggunaan talas $25 \%$ dan $50 \%$ memberikan nilai organoleptik yang lebih baik dibanding perlakuan penggunaan tepung terigu 100\% (kontrol). Penggunaan talas dalam jumlah yang lebih banyak menunjukkan nilai rasa semakin rendah, namun tekstur pastel yang dihasilkan dengan substitusi tepung terigu 
sampai $75 \%$ masih menunjukkan nilai yang baik dan renyah namun penggunaan talas $100 \%$ memberikan nilai tekstur yang rendah dan kurang disukai.

Rasa merupakan faktor yang paling penting dalam menentukan keputusan bagi konsumen untuk menerima atau menolak suatu makanan atau produk pangan. Meskipun parameter lain nilainya baik, jika rasa tidak enak atau tidak disukai maka produk akan ditolak (Soekarto, 1985).

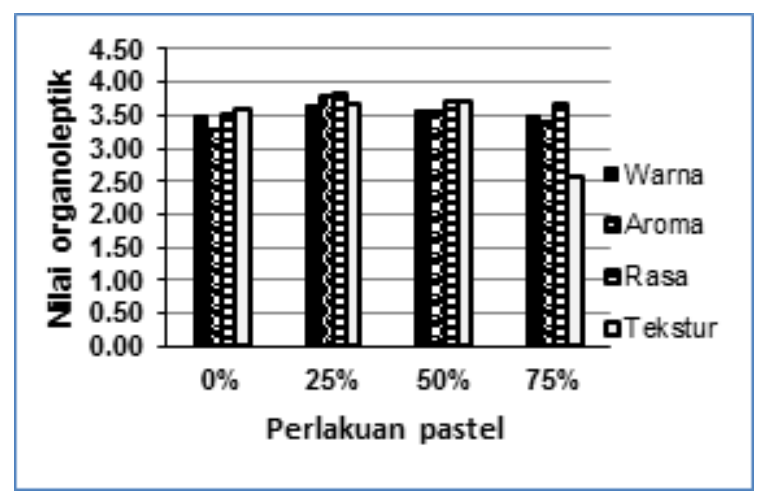

Gambar 8. Nilai Organoleptik Pastel Talas

\section{Roti Talas}

Hasil uji organoleptik roti talas menunjukkan bahwa perlakuan formula penggunaan talas $25 \%$ memberikan nilai yang optimal dan dapat dikatakan menyamai roti dengan penggunaan tepung terigu $100 \%$ baik warna, aroma, rasa maupun tekstur roti yang dihasilkan. Substitusi terigu dengan talas untuk pembuatan roti dapat digunakan sampai $75 \%$ namun teksturnya kurang halus seperti terlihat pada Gambar 10. Menurut Saptoningsih (2013) pembuatan roti dengan pencampuran tepung talas sebagai bahan sustitusi akan mengurangi kandungan gluten adonan dimana gluten berperan dalam pembentukan struktur roti, pengembangan adonan dan volume roti. Apabila substitusi menggunakan talas dalam jumlah yang lebih banyak maka untuk mendapatkan produk dengan mutu yang masih dapat diterima oleh konsumen perlu ditambahkan CMC (karboksimetil selulosa).

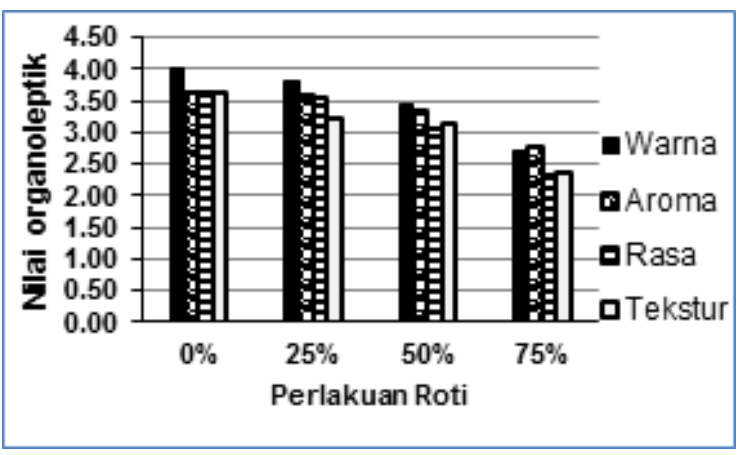

Gambar 9. Nilai Organoleptik Roti Talas

\section{Cookies Talas}

Nilai organoleptik cookies ditunjukkan pada Gambar 10. Penggunaan talas $50 \%$ memberikan nilai tertinggi dibanding penggunaan terigu $100 \%$ dan perlakuan lain baik dari segi warna, rasa dan tekstur. Pada pembuatan kue kering penggunaan talas $100 \%$ masih memberikan hasil yang cukup baik dengan rasa yang tidak jauh berbeda dengan penggunaan terigu $100 \%$ namun tekstur cookies yang dihasilkan cenderung lebih kasar seperti terlihat pada Gambar 11.

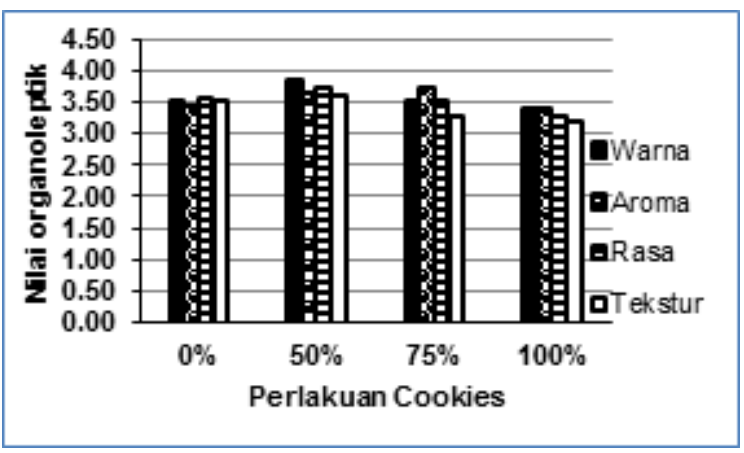

Gambar 10. Nilai Organoleptik Cookies Talas

Sesuai pendapat Sufi (2009) untuk kue kering lebih cocok digunakan tepung terigu dengan kandungan protein yang rendah. Menurut US Wheat Associates (1983) bagian protein dalam tepung tidak selamanya menunjukkan kuatnya tepung. Banyak tepung lunak berprotein rendah tidak menghasilkan kue kering yang empuk dan rata, hal ini terutama tergantung pada sifat kasar dan tegarnya jenis gluten. Tekstur cookies yang kasar dapat juga disebabkan karena talas yang digunakan dari talas blok yang kemudian dihaluskan 
dengan menggunakan blender lalu diayak dengan ayakan tepung biasa. Dalam hal ini sebaiknya menggunakan ayakan Mesh yang lebih halus.
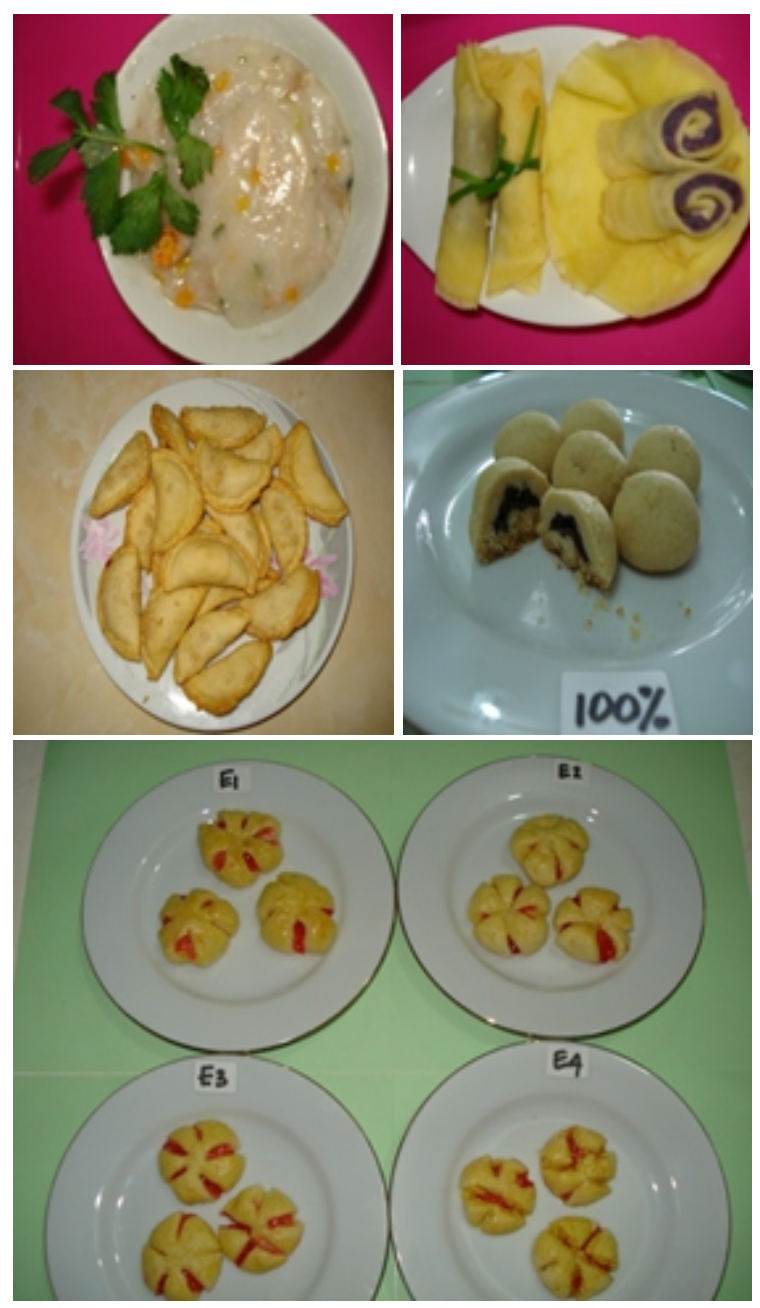

Gambar 11. Bubur Talas, Pancake Talas, Pastel Talas, Cookies Talas dan Roti Talas

Berdasarkan pengamatan secara organoleptik baik warna, aroma, dan rasa produk bubur, pastel dan pancake dari talas ini hanya tahan selama 1 hari pada penyimpanan suhu kamar, sedangkan produk roti yang dibungkus dengan kantong plastik polipropilen lalu ditutup dengan klim panas menggunakan sealer, kemudian disimpan pada suhu kamar, menunjukkan ketahanan simpan secara organoleptik baik warna, aroma maupun rasa tahan sampai 3 hari, namun tekstur roti pada hari ke 3 menjadi agak kering. Produk cookies yang disimpan dalam kemasan kotak plastik yang ditutup rapat dengan selotip, setelah diuji secara organoleptik baik warna, aroma, rasa, tekstur dan penampakan tahan sampai 7 bulan penyimpanan pada suhu kamar dan tidak terkena cahaya matahari langsung. Hasil Uji organoleptik yang memberikan nilai yang optimal terhadap produk roti adalah penggunaan talas $25 \%$ dan cookies adalah penggunaan talas $50 \%$. Hasil uji kimia produk tersebut seperti terlihat pada Tabel 2 .

Mengacu pada SNI 01-2973-2011 tentang biskuit maka cookies dengan penggunaan talas blok $50 \%$ memenuhi persyaratan kandungan lemak dan kalorinya, dimana kandungan lemak minimal $9,5 \%$ dan kalori minimal $400 \mathrm{kal}$.

Produk makanan kering yakni cookies talas sesuai dengan perlakuannya dan dikemas dalam kotak plastik bertutup kemudian supaya tidak masuk semut atau udara diberi selotip yang disimpan pada suhu kamar. Pengamatan ketahanan simpan dilakukan secara organoleptik terhadap penampakan, aroma, rasa dan tekstur cookies tersebut.

Tabel2. Kandungan Lemak, Protein, Karbohidrat dan Kalori Roti Talas 25\% dan Cookies Talas 50\%

\begin{tabular}{|l|l|l|}
\hline \multirow{2}{*}{ Kandungan } & \multicolumn{2}{|c|}{ Tiap 100 gram Produk } \\
\cline { 2 - 3 } & $\begin{array}{c}\text { Roti Talas } \\
25 \%\end{array}$ & $\begin{array}{c}\text { Cookies } \\
\text { Talas } 50 \%\end{array}$ \\
\hline Lemak & $45,61 \%$ & $30,14 \%$ \\
\hline Protein & $1,51 \%$ & $0,92 \%$ \\
\hline Karbohidrat & $45,71 \%$ & $47,02 \%$ \\
\hline Kalori & $599 \mathrm{kal}$ & $463 \mathrm{kal}$ \\
\hline
\end{tabular}

Semua perlakuan menunjukkan hasil cookies yang masih baik secara organoleptik baik penampakan, aroma, rasa maupun tekstur sampai 7 bulan penyimpanan. Menurut Supriyadi (2009) umur simpan atau waktu kadaluarsa merupakan suatu rentang waktu yang menyatakan bahwa produk masih dalam keadaan aman dikonsumsi, memenuhi sifat sensoris, kimia, fisik dan mikrobiologis, sesuai dengan pernyataan nilai gizi yang tercantum dalam label. Produk dinyatakan kadaluarsa apabila indikator bahwa nilai gizi bahan yang terkandung didalamnya sudah mendekati batas minimal sehingga apabila dikonsumsi sudah kurang memberikan manfaat lagi bagi tubuh, sifat fisik seperti 
kekerasan, kekempalan, kerenyahan atau warna dan sebagainya telah mendekati nilai penolakan konsumen meskipun kandungan gizi kemungkinan masih baik, serta sifat sensoris seperti bau yang sudah tidak disukai atau kurang disukai.

Masa simpan cookies yang lebih lama didukung dengan kadar airnya yang rendah dan relatif stabil selama penyimpanan, hal ini dapat disebabkan karena kondisi pengemasan dan penyimpanan yang juga baik. Pengemasan cookies ini dalam kotak plastik yang ditutup rapat dengan menggunakan selotip serta disimpan pada tempat yang tidak terkena cahaya matahari langsung. Sesuai SNI biskuit 01-2973-2011 kadar air biskuit dipersyaratkan maksimal $5 \%$. Kadar air sangat berpengaruh terhadap mutu bahan pangan dan pada umumnya keawetan bahan pangan mempunyai hubungan yang erat dengan kadar air yang dikandungnya. Bahan pangan atau makanan dengan kadar air yang lebih rendah umumnya mempunyai ketahanan yang lebih lama (Herman, 1991).

Tabel 3. Hasil analisis kadar air cokies talas

\begin{tabular}{|l|c|c|c|c|}
\hline \multirow{2}{*}{ Perlakuan } & \multicolumn{4}{|c|}{ Kadar Air (\%) Bulan ke } \\
\cline { 2 - 5 } & 0 & 1 & 2 & 3 \\
\hline E1(0\%/kontrol) & 6,53 & 6,67 & 6,47 & 6,11 \\
\hline E2 (50\%) & 5,20 & 5,54 & 5,60 & 5,74 \\
\hline E3 (75\%) & 5,36 & 5,64 & 5,87 & 5,71 \\
\hline E4 (100\%) & 4,41 & 5,19 & 5,15 & 5,34 \\
\hline
\end{tabular}

Penggunaan talas $100 \%$ pada penelitian ini memberikan kadar air yang lebih rendah dibanding perlakuan lain. Rendahnya kadar air pada cookies dengan penggunaan $100 \%$ dapat disebabkan karena pati talas memiliki viskositas yang tinggi sehingga menghasilkan cookies yang lebih rendah kadar airnya (Apriani et al, 2011).

\section{KESIMPULAN}

Talas blok yang dibuat dari talas jenis Xanthosoma sagittifolium mengandung kadar air $12,40 \%$, kadar abu 1,12\%, kadar pati $73,37 \%$, amilosa $2,88 \%$, amilopektin $70,49 \%$ dan protein $3,4 \%$. Talas blok dapat digunakan untuk aneka produk makanan pengganti beras atau substitusi tepung terigu baik makanan basah seperti bubur, makanan semi basah seperti pancake, pastel dan roti serta makanan kering seperti cookies. Substitusi talas blok pengganti tepung terigu dan tepung beras dengan hasil optimal dan lebih disukai panelis secara organoleptik yakni untuk roti dan pastel dengan penggunaan talas $25 \%$, pancake dengan substitusi talas blok $50 \%$ dan bubur dengan substitusi talas blok $30 \%$ serta cookies dengan penggunaan $50 \%$ talas dengan kadar air $5,20 \%$ dan selama 3 bulan penyimpanan terjadi sedikit peningkatan kadar airnya yakni $5,74 \%$.

\section{DAFTAR PUSTAKA}

Apriani, R.N., Setyadjit dan Arpah M. 2011. Karakterisasi empat jenis umbi talas varian mentega, hijau, semir dan beneng serta tepung yang dihasilkan dari ke 4 varian umbi talas. Jurnal IImiah dan Penelitian IImu Pangan No. 1 Vol.1. Departemen IImu dan Teknologi Pangan IPB. Bogor.

Badan Standardisasi Nasional. 2009. SNI 01-3549-2009. Tepung beras. BSN. Jakarta.

Badan Standardisasi Nasional. 2009. SNI 01-3751-2009. Tepung terigu. BSN. Jakarta.

Badan Standardisasi Nasional. 2011. SNI 01-2973-1992. Biskuit. BSN. Jakarta.

Fardiaz, Srikandi. 1989. Mikrobiologi pangan. IPB. Bogor.

Herman, A.S. 1991. Pengetahuan bahan dan produk industri kecil pengolahan pangan. Direktorat Industri Pangan. Jakarta.

Hermianti, W., Firdausni, Kasim, M., Monandes, V., dan Rovina, E. 2010. Pengembangan teknologi dan analisis tekno ekonomi pembuatan talas blok (tepung, diversifikasi produk). Baristand Industri Padang. 
Indrasti, D. 2004. Pemanfaatan tepung talas Belitung (Xanthosoma sagittifolium) dalam pembuatan cookies. Skripsi IPB. Bogor.

Prihatman, K. 2000. Sistim informasi manajemen pembangunan di pedesaan. Bappenas. Jakarta.

Rahmawati, Wida, Kusumastuti Y.A., Aryanti, N. 2012. Karakterisasi pati talas (Colocasia esculenta (L.) schott) sebagai alternative sumber pati industri di Indonesia. Jurnal Teknologi Kimia dan Industri Vol. 1 No. 1. Jurusan Teknologi Kimia Fakultas Teknik Universitas Diponegoro. Semarang.

Richana, N., Sunarti, T. C. 2004. Karakterisasi sifat fisikokimia tepung umbi dan tepung pati dari umbi ganyong, suweg, ubikelapa, dan gembili. Jurnal pascapanen, 2004, 1.1: 29-37.

Ridal, S. 2003. Karakteristik sifat fisiko kimia tepung dan pati talas (Colocasia esculenta) dan kimpul (Xanthosoma $s p)$ dan uji penerimaan a-amilase terhadap patinya. Skripsi Fakultas Teknologi Pertanian IPB. Bogor.

Saptoningsih. 2013. Membuat tepung talas dan alternative pemanfaatannya. BBPP. Lembang.

Sediaoetama, Djaeni, A. 1996. Ilmu gizi. Dian Rakyat. Jakarta.

Slamet, D.S. dan Ig.Tarkotjo. 1980. Majalah gizi dan makanan jilid 4. Pusat Penelitian dan Pengembangan Kesehatan. Depkes RI. Jakarta.
Soekarto, S.T. 1985. Penilaian organoleptik untuk industri pangan dan hasil pertanian. Bhratara Karya Aksara. Jakarta.

Soekarto, S.T., Supiarti, A., Sirait, S.D. Yanita, R., Sutrisniati, D., Rienoviar, M. Isyanti, D. Kusmayadi, D. Abdurachman. 2008. Pengembangan diversifikasi produk untuk industri pangan berbasis pangan lokal. Laporan penelitian IImu Pengetahuan Terapan. BBIA. Bogor.

Srihari, E. dan Lingganingrum, F.S. 2014. Tepung talas sebagai pengganti tepung terigu. Universitas Surabaya.

Sufi, S.Y. 2009. Sukses bisnis roti unyil dan pizza mungil. Kriya Pustaka. Jakarta.

Suismono. 2011. Teknologi pembuatan tepung dan pati ubi-ubian untuk menunjang ketahanan pangan. Majalah Pangan 10 (37). Puslitbang Bulog. Jakarta.

Supriyadi. 2009. Pangan kadaluarsa, siapa yang bertanggung jawab. Foodreview Vol. IV No. 11. PT. Media Pangan Indonesia. Bogor.

Universitas Hasanuddin. 2011. Penggunaan tepung sukun sebagai bahan pengganti sebagian tepung terigu pada pembuatan pancake dan bakpao. Univ. Hasanuddin. Makassar.

U.S. Wheat Associates.1983. Pedoman pembuatan roti dan kue. Bakers Handbook on practical baking. U.S. WheatAssociates. 